\title{
The Limits and Potential of Liberal Peacebuilding for Human Security
}

\author{
Sorpong Peou
}

\begin{abstract}
The overall record of peacebuilding as a post-Cold War liberal project has proved to be more positive than negative, especially in conflict termination. However, the peacebuilding agenda has had its limits in terms of progress in democratization, judicial institution-building and economic development, despite potential for greater success. Peacebuilders are more likely to succeed in transforming societies torn by armed conflict if they can avoid making the process excessively competitive. Democratization and capitalist development are already competitive processes, and the pursuit of retributive justice takes the form of judicial punishment. Together these strategies can form a recipe for competition and conflict, especially in institutionally weak states where the history of distrust among warring factions or former enemies is long and intractable.
\end{abstract}

Keywords peacebuilding, armed conflict, micro-disarmament, democratization, retributive justice, economic development

\section{Introduction}

The term peacebuilding has been subject to disagreement and theoretical debate, primarily because of the different ideological positions adopted by scholars, practitioners, policymakers, and activists (Newman 2009; Newman, Paris, and Richmond 2009; Newman and Richmond 2006). They all seem to agree on the need for peacebuilding; however, they differ on how to achieve peace, what peace means, and how to measure degrees of success (Fischer 2009, 90-91). For some, peacebuilding may even be a "waste of time" (Fisher and Zimina 2009). For others, there are limits to what peacebuilders can do. Some who see the limits of peacebuilding are still optimistic, thinking that the liberal project can still be saved (Paris 1997; 2009). Still others, also critical of liberal peacebuilding, see the need to go beyond this agenda (Richmond 2003; Pugh 2009).

This essay does not weigh in on the endless debate about what peace means,

(C) 2014 The Institute for Peace and Unification Studies, Seoul National University

ISSN 2288-2693 Print, ISSN 2288-2707 Online 
but simply argues that peacebuilding as a post-Cold War neo-liberal project has proved to be more successful than its critics think but less successful than its proponents had hoped. The overall record of peacebuilding is positive and the project still has a great deal of potential when assessed in terms of its ability to terminate armed conflict. The neo-liberal peacebuilding agenda has its limits, but it still has potential for greater success. Because they are primarily interested in ensuring their own security, states are unlikely to become far more altruistic by allocating more resources for peacebuilding in other states-unless their national interests are also better served. There is thus a need to do more with less, but doing less means focusing on fewer areas of peacebuilding. The pursuit of retributive justice in post-war or war-prone societies has proved to be the least effective strategy and may work against the peacebuilding agenda, especially in the early stages of the process. Those in possession of weapons are unlikely to disarm unless they enjoy acceptable degrees of security, democratic rights, and economic wellbeing. Thus, disarmament, democratic and legal institution building, and economic development have their challenges; however, they remain promising peacebuilding strategies.

\section{Peacebuilding as Process in the Liberal Agenda}

Academic literature on international peacebuilding has become a growth industry since the 1990s, but the term was used even earlier (Mitrany 1966, 96; Galtung 1975). In 1992, then-UN Secretary General Boutros Boutros-Ghali popularized the term, defining it as "action to identify and support structures which will tend to strengthen and solidify peace in order to avoid a relapse into conflict" (Boutros-Ghali 1992, 11).

Peacebuilding means different things to different people, and how peace can be achieved depends on how one sees and measures it (Heathershaw 2008). Michael Barnett and his associates draw our attention to the fact that proponents agree that peacebuilding is a good thing, but disagree on why it is so and how to achieve it. For some observers, the process proceeds after military intervention in the form of either peacekeeping or humanitarian intervention. That is, peacebuilding begins when armed conflict is over and it aims to prevent a relapse into violent conflict. For others, peacebuilding means taking preventive action before violent conflict breaks out. Still for others, peace means more than the absence of armed conflict or war. Peace is defined in positive terms: the absence of structural violence or injustice, such as hunger, poverty, and unemployment (Barnett, Kim, O'Donnell, and Sitea 2007, 37-44). Advocates also focus on different policy goals and instruments. Barnett and his associates illustrate the point by referring to the fact that "when the Bush administration thinks of peacebuilding it imagines building market-oriented democracies, 
while the UNDP imagines creating economic development and strong civil societies committed to a culture of nonviolent dispute resolution" (Barnett, Kim, O'Donnell, and Sitea 2007, 44).

The terminological ambiguity of peacebuilding is inevitable for the simple reason that its advocates are numerous, if not countless, and they subscribe to different ideological positions, interests, and policy priorities. The so-called "international peacebuilding community" is made up of a myriad of actors, including states, and international organizations, (including the United Nations, the European Union, international non-profit organizations) and also corporate entities, civil society actors, and even individuals (Fisher and Zimina 2009, 15-17; Chigas and Woodrow 2009, 51-54; Weitsch 2009; Rittberger and Fischer 2008). Even within the UN system itself, there are different agencies and institutions involved in peacebuilding; among these is the Peacebuilding Commission.

Contemporary peacebuilding, however, is known as a liberal project (Newman, Paris, and Richmond 2009). Advocates may differ on what peacebuilding means and how it can be implemented, but liberals of various persuasions prescribe armed conflict prevention in post-conflict and conflictprone societies through various policy instruments. As Biersteker ably puts it, "Although there is no consensus on the definition of and the best practices for achieving peacebuilding, it is in practice a liberal project." He emphasizes that "peacebuilding is broadly constituted on the premise that democratic institutions and market mechanisms will ultimately provide the stable foundation for peace, both internally and externally" (2007, 39). Also, Roland Paris has observed that liberal peacebuilding concentrates on the two most fundamental forms of liberalization-namely, democratization and marketization (Paris 2006). The UN Peacebuilding Commission's core mandate, for instance, aims to prevent conflict in countries emerging from civil war. As a UN aid coordination body, the Commission also advances the liberal agenda. As one writer puts it, "In general... liberal democracy and the rule of law, plus macroeconomic stability, deregulated markets and security of property, are the standards to which the international community is at least nominally committed, and these are reflected in the [Peacebuilding Commission]'s work" (Jenkins 2008, 13).

Overall, the post-Cold War agenda for peacebuilding is broader than democratization and marketization and can be defined more precisely as "neoliberal" with its emphasis on several processes that require global intervention: micro-arms control and disarmament, political liberalization, marketization, and legal institutionalization. Peacebuilding, however, is not based on the use of military force or "a widely accepted justification for the permanence of war," as noted by some scholars (Heathershaw 2008, 621). Peacebuilding differs from peacekeeping or peace enforcement in that the latter two policy instruments involve the potential use of force. In a nutshell, peacekeeping traditionally aims to create a buffer zone separating parties to armed conflict based on their consent, 
whereas peace enforcement aims to put an end to armed conflict without waiting for their consent. Peacebuilding may take place in the midst of or after peacekeeping or peace enforcement activity, but it is a process distinct from the latter two in that it involves other processes after armed conflict ends.

Disarmament, Demobilization, and Reintegration (DDR) and demining have been recognized as part of peacebuilding-a process of security institution building. The DDR process involves collecting, regulating, and disposing of small arms and light weapons, downsizing and disbanding armed forces, and reintegrating former combatants into the social, economic, and political life of civilian communities (Özerdem and Knight 2004). Literature on microdisarmament (related to small arms and light weapons) has grown in recent years (O’Dwyer 2006; Batchelor 2002; Smith 2000; Muggah 2001; Muggah and Griffiths 2002; Thakur and Maley 1999). Disarming involves banning and destroying landmines as well as small arms and light weapons (SALW). The DDR process also includes reform of the security sector (Evans 2008).

Political liberalization in the form of democratization in post-conflict societies through the holding of free and fair elections remains the key aspect of neo-liberal peacebuilding. This type of assistance means "aid specifically designed to foster a democratic opening in a nondemocratic country or to further a democratic transition in a country that has experienced a democratic opening" (Carothers 1999, 6). As Krishna Kumar and Jeroen de Zeeuw observe, "International donors believe-with considerable justification-that democracy offers the best chance to promote peace and heal the wounds of war in postconflict societies" (Kumar and de Zeeuw 2006, 5). Western democratic states see themselves as "democracy promoters" and providers of international democracy assistance (Feher 2000, 32; Carothers 2000, 185-186). International organizations, especially the UN, have made similar efforts to promote democracy (Diamond 1995, 31-38; Joyner 1999, 333; White 2002, 69; World Bank 1998). Regional organizations, including the European Union, the Organization of African States, the Inter-Parliamentary Union, and the Commonwealth Secretariat, have also become actively involved in democracy promotion. National and international NGOs are another set of democracy promoters.

The execution of global criminal justice has also been viewed as part of an integrated peacebuilding and reconstruction process. For instance, ad hoc international criminal tribunals "have significantly contributed to peace building in postwar societies" (Akhavan 2001, 9). Proponents remain optimistic about the positive impact of criminal trials on peace, ever confident that this process helps end armed conflict and protects against mass murder (Akhavan 2009). Mark Freeman notes that "the importance of criminal trials remains unrivaled. No other mechanism is perceived to have a greater impact on deterrence, public confidence in the state's ability and willingness to enforce the law, and a victim's sense of justice" (Freeman 2002, 10). Retributive justice also contributes to the 
process of democratization, as "the continuing legacy of impunity proved a serious impediment to democratization" (Roht-Arriaza 1999, 484). The liberal idea of peace through retributive justice rests on the belief that legal impunity exacerbates human rights violations (Goldstone 1995). The legal norm of accountability is seen as capable of addressing this problem, if peace is to be built.

Economic reconstruction and development based on capitalism remains another key conceptual pillar of the neo-liberal peacebuilding agenda. Global developmentalists stress the need to empower individuals, moving "from security through armament to security through sustainable human development" (UNDP 1994, 24). They see compatibility between the strategies of responsibility to protect people and empower them (Hasegawa 2007). They further advocate the need to shift policy commitment away from excessive military spending to human development, with an ethical commitment to development assistance through programs like health and education (Penz 2001). Since the beginning of the new century this globalist approach has emphasized the need to develop and implement new global policy commitments, most notably the Millennium Development Goals (MDGs) adopted in 2000 at the Millennium Summit (organized by the United Nations and aimed at generating international commitment to human security through aid allocation). The overall thinking rests on the assumptions that peace cannot be sustained without marketbased economic development and that national integration into the neo-liberal economic world order is the way of peace (Fisher and Zimina 2009, 19).

In short, peacebuilding as a global enterprise has enjoyed a high level of normative commitment and institutional development. Steps have been taken to implement the neo-liberal agenda in countries prone to violent conflict, but this does not mean that the agenda has always been implemented effectively. The question is whether this global endeavor has made a significant difference and left enduring legacies in post-war societies, when assessed in terms of progress on micro-disarmament, democratization, legal institutionalization, and marketdriven development.

\section{Some Empirical Evidence of Peacebuilding Initiatives}

Does the neo-liberal peacebuilding agenda have a strong empirical record? One way to answer the question is to look at the overall trend of interstate and intrastate conflicts (Mack 2008). According to some (Barnett, Kim, O’Donnell, and Sitea 2007, 35), the picture "is very mixed. ... Nearly 50\% of all countries receiving assistance slide back into conflict within five years, and $72 \%$ of peacebuilding operations leave in place authoritarian regimes." While this assessment may be useful, it is also important to look at each peacebuilding operation more closely in order to better assess the degree to which it succeeds 
or fails, and to explain why. Comparative case studies can be useful in terms of helping scholars assess whether peacebuilders succeed in disarming, demobilizing and reintegrating former combatants, clearing land mines, building democratic, legislative and legal institutions, and ensuring sustainable economic development in post-conflict countries. In this article four country cases-Cambodia and Timor-Leste in Southeast Asia, and Burundi and Sierra Leone in Africa-will be analyzed comparatively to show that the process of peacebuilding in war-torn and post-war countries has been positive, despite numerous challenges.

\section{Cambodia}

Cambodia has a long history of political violence and armed conflict beginning with an armed rebellion in the late 1960s followed by: a civil war that raged throughout the first half of the 1970s; the Khmer Rouge reign of terror from 1975 to 1978; a Vietnamese invasion in late 1978; and the subsequent war that lasted until 1998. The UN intervened after the warring factions signed a peace agreement, on October 23, 1991, by dispatching the United Nations Advance Mission in Cambodia (UNAMIC) to prepare the way for the United Nations Transitional Authority in Cambodia (UNTAC), which had a broader mandate that especially disarmament and the organizing and holding of national elections. UNAMIC was tasked only with the responsibility to ensure that the warring factions observed the agreed ceasefire and to initiate as well as provide landmineawareness and training of civilian populations (Peou 1997).

Although UNTAC (deployed to the country from March 1992 to late 1993) failed to complete its disarmament efforts because of resistance from the warring factions (most notably the Khmer Rouge led by Pol Pot), later disarmament efforts proved to be more successful. In the early 1990s, somewhere between 319,000 and 462,000 small arms were in circulation. A seven-year disarmament program (2000-2006) - designed, among other things, to strengthen the legal framework, ensure effective weapons collection and destruction, develop stockpile management, and build police capacity-produced some positive results. The program saw some $80 \%$ of the arms brought under government control or destroyed (Wilkinson and Hart-Dyke 2006). The demining process also produced positive results (Peou 2013a). This success story began especially after the collapse of the Khmer Rouge movement in 1998 and the end of the war shortly afterwards.

Another bright spot in the process of peacebuilding has been strong and steady economic growth and its positive impact on society with a gross domestic product (GDP) growth rate of more than 8\% per year between 2004 and 2012. According to the Asian Development Bank, the economy was expected to grow by $7.2 \%$ in 2013 and to pick up to $7.5 \%$ in 2014 . Domestic consumption has expanded by an estimated $9.5 \%$ per year and made the biggest contribution to GDP growth. Foreign investment has also increased and helped fund new 
industries, such as the manufacture of automotive parts and processing of agricultural products, as well as diversifying garment production into highervalue products. Because of good performance in agriculture, poverty has also declined to below 20\%, compared to nearly 50\% in the early 1990s (Asian Development Bank 2013, 219).

In general, Cambodia has maintained peace and become economically more developed, but the process of democratization has weakened considerably. The violent coup staged by Second Prime Minister Hun Sen in July 1997 led to power consolidation by his political party, the Cambodian People's Party (CPP). Although the 1993 election was considered somewhat free and fairthough marred by political violence and intimidation-this was not the case with subsequent elections. A hegemonic-party system has now emerged, with Hun Sen remaining the dominant political figure facing a weak political opposition with no real prospects for winning elections. Hun Sen has also dominated his political party, which has tightened control over the executive, legislative and judicial branches of government, as well as the armed forces and civil society (Heder 2012; Springer 2010; Peou 2014; Peou 2007). This does not mean the hegemonic-party system is here to stay forever, as the parliamentary elections held in 2013 showed when the overconfident CPP won, but lost an unexpectedly large number of seats to the opposition. The CPP leadership has sought to do what it could to restore its hegemonic-power status, but this ambition has created political instability. Armed politics reappeared after the national elections in 2013, when Hun Sen deployed troops and tanks around the capital city to prevent any protests against the election results.

"Authoritarian peace" has been maintained amidst the pursuit of retributive justice against the Khmer Rouge, which began when the Cambodian government and the United Nations agreed in 2004 to establish the Extraordinary Chambers in the Court of Cambodia (ECCC). On July 26, 2010, the ECCC Trial Chamber sentenced a former Khmer Rouge official to 19 years in prison, but the ECCC Supreme Court Chamber increased his sentence to life imprisonment. Several other top Khmer Rouge leaders have also been brought to justice. The CPP leadership, however, would not want to see the ECCC succeed far beyond what has been achieved so far given the fact that the CPP is made up of former Khmer Rouge leaders who would not want to face retributive justice themselves (Peou 2013b). Overall, the judicial and legal systems have become instruments of ongoing CPP hegemonic politics. The state leadership has used courts to consolidate its power by taking legal action against its political opponents. Opposition members of parliament have been expelled from the legislative body and even brought to court for trial. Legal cases brought against CPP officials by opposition members have almost always failed (Peou 2011). 


\section{Timor-Leste}

Timor-Leste also suffered tremendously from the ravages of colonization, war, and armed violence. The Portuguese colonized the territory in the nineteenth century and abandoned its rule early in 1975. A civil war then broke out when two armed groups - the leftist FRETILIN (Revolutionary Front of Independent East Timor) and the right-wing Timorese Democratic Union (TDU)—engaged in a struggle for control of the former colony. In December 1975, armed forces of Indonesia invaded the territory and Indonesia annexed Timor-Leste as its 27th province. The Indonesian armed forces continued to wage a counter-insurgency war against the leftist FRETILIN's military wing (East Timorese National Liberation Army or FALINTIL) and committed mass atrocities against local people. By 1979, approximately 200,000 Timorese had died of armed conflict and starvation (Katzenstein 2003).

Armed conflict and violence against East Timorese did not end when Indonesian President B. J. Habibie reversed the hardline policy of his predecessor, President Suharto. In January 1999, Habibie announced that his government would let the East Timorese determine their own political future in a referendum (Smith 2003). During the summer of 1999, Indonesian soldiers and militias drove between 400,000 and 600,000 villagers out of their homes. Even after $98.5 \%$ of those who cast their votes on August 30, 1999 favored independence, threats to the security of the Timorese did not end.

The violence committed against East Timorese by the Indonesian and proIndonesia militias abated when an Australian-led multinational force under UN auspices (International Force for East Timor or INTERFET) entered East Timor in September 1999. However, in 2003, small groups of armed men with extensive military training based in West Timor infiltrated East Timor and killed many villagers (Smith 2003, 33). In 2006, Timor-Leste fell back into violence when armed clashes erupted, in April and May, among military and police factions in Dili threatening civil war (United Nations 2006; Hughes 2009).

Subsequently, armed clashes between the military and police subsided but political divisions remained. Between 2007 and 2013, the politico-security situation improved in that there were no serious violent incidents similar to those in 2006. The one major incident during this four-year period was an unsuccessful attempt, in February 2008, by a group of former soldiers to assassinate Prime Minister Xanana Gusmao and President Jose Ramos Horta in which Horta was badly wounded.

INTERFET was successful in terms of disarming former combatants. According to Michael Smith and Maureen Dee (2003, 50), "East Timor quickly became a less lethal society than many 'peaceful' and developed countries." Disarmament efforts were successful for several reasons, the most important being that the pro-Indonesia armed militias returned to West Timor taking their weapons with them and the international forces quickly confiscated those 
weapons that remained in East Timor. Although armed FALINTIL members remained within specified cantonments, they possessed neither heavy weapons nor landmines.

Since 2006 peace has become more evident and the economy has continued to grow $(12.8 \%$ in $2009,9.5 \%$ in $2010,10.6 \%$ in 2011 , and $10 \%$ in 2012 ), but economic challenges persist. According to the Asian Development Bank, strong economic growth is expected to stay around 10\% in 2013 and 2014 (Asian Development Bank 2013, 219), with oil revenues and increased government expenditures being the main engines of economic growth. Poverty remains a critical social issue, however. According to the World Bank's 2008 Timor-Leste poverty survey, the population living below the national official poverty line of US $\$ 0.88$ per capita per day grew from $36 \%$ in 2001 to $50 \%$ in 2007 , with increases in both rural and urban areas (World Food Program 2013). In 2012, about $41 \%$ of the population lived below the poverty line.

The people of Timor-Leste now enjoy more democratic and human rights than they did under Indonesian rule. The road to democracy began when the United Nations Transitional Administration in East Timor (UNTAET) was tasked with a Security Council mandate to set up a democratic government. In 2001, the country elected a Constituent Assembly to draft a constitution. In April 2002, presidential elections took place and Xanana Gusmao, a former resistance commander, became the first president. Throughout the 2000s, the presidential, legislative, and local elections in Timor-Leste were considered to be generally free and fair, as demonstrated by the fact that no political party was in position to control the electoral process. Nevertheless, this does not mean that democracy in the country has now been consolidated (Shoesmith 2012; Brown and Gusmao 2009).

The judicial and legal systems remain institutionally weak despite global efforts to implement a process of retributive justice. The country has established a rudimentary legal system, but its justice system remains among the weakest sectors of government (Index of Economic Freedom 2013a). International efforts to bring criminals to justice did not leave a positive legacy. Even proponents of retributive justice have found it appalling that the Special Panels on Serious Crimes and the Court of Appeal have hardly functioned. The Serious Crimes process did not prepare Timor-Leste for the task of judicial and legal institution building. The Defense Lawyers Unit did not provide adequate legal services for the accused. The defense lawyers themselves lacked the expertise and experience necessary to defend their clients.

\section{Burundi}

The case of Burundi also shows the limits of success in peacebuilding efforts. Armed conflict has now ended and peace is being maintained. Although a constitution was adopted in 1992 to introduce multiparty politics, the 
following year saw ethnic violence become widespread after the newly elected Hutu president, Melchior Ndadaye of the Front for Democracy in Burundi (FRODEBU), was assassinated. The result was that a civil war erupted in 1993 and lasted for 12 years, leaving more than 300,000 people dead. The civil war lingered, as attempts to end it were only partially successful. In 2000, the warring factions signed what came to be known as the Arusha Peace and Reconciliation Agreement for Burundi, in which they agreed to establish three justice mechanisms: an international commission of judicial inquiry, a national truth and reconciliation commission, and an international criminal tribunal.

By the end of 2002 most warring factions also agreed to participate in the democratic process. In August 2004, they further agreed to establish new democratic institutions aimed at striking a balance of political interests between the two major ethnic groups and ensuring the holding of future elections. Sporadic violence did not end until the last significant faction of the National Liberation Forces (NLF) agreed to a tentative ceasefire in 2007, followed by the NLF's agreement to disarm in 2009 and its emergence as a political party.

From March 2004 to December 2008, the Multi-Country Demobilization and Reintegration Program (MDRP) succeeded in demobilizing some 26,000 adult combatants and around 3,000 child combatants. From March 2009 to December 2011, the MDRP further sought to demobilize the NLF fighters. Findings show mixed results in the disarmament efforts. According to one study, "significant numbers of ex-combatants did not surrender their weapons when demobilizing" and only "relatively few weapons had been turned in" (Avendano and Brown 2011).

The 1993 assassination of Ndadaye not only resulted in civil war but also destroyed the nascent democracy. The extent to which the country has now become democratic is a matter of debate. Although the process of democratization was reintroduced in 2005, when the country held its local and national elections, there is very little evidence of progress since then. Freedom House $(2005 ; 2012)$ considered the country "partly free" in 2005, with the same rating of 5.0 for freedom, civil liberties, and political rights (on a scale of 1 to 7 , with 7 being least free). The 2012 scores remained unchanged.

Economic development in Burundi has even been less impressive than that in either Cambodia or Timor-Leste. Its GDP growth rate has been weak, ranging between $3.5 \%$ in 2009 and $4.5 \%$ in 2013. Although services and manufacturing have expanded, the economy continues to depend on the primary sector. While rich in natural resources, the country remains one of the poorest in Africa. Its human development index shows that the country has improved in recent years, but it is still ranked 166th out of 169 countries in the world. Some $67 \%$ of the population still lives below the poverty line, compared to an African average of 42.3\% (African Development Bank 2011).

Although domestic and international observers judged the 2005 local and 
national elections to be generally legitimate and reflective of the people's will, political violence and intimidation persisted. Political tension continued even after an independent commission was established with the responsibility to prepare for elections scheduled for 2010, and after a new electoral code was adopted. After it won the local elections in May with almost two-thirds of the vote, the largely Hutu National Council for the Defense of Democracy and the Forces for the Defense of Democracy (CNDD-FDD) began to restrict political space (Nindorera 2012). Opposition parties then boycotted the June presidential elections and the July parliamentary polls. Political repression intensified, and after having captured $81 \%$ percent of the parliamentary vote, the CNDD-FDD was in a position to control the presidency and dominate the legislative body. According to the African director at Human Rights Watch, "Instead we have seen [since the 2010 election] the systematic targeting of former rebel combatants and members of the political opposition. Many of those who refused to succumb to pressure to join the CNDD-FDD have paid with their lives" (Human Rights Watch 2012b). As the CNDD-FDD consolidated its power base, violent repression continued. As of 2013, the country cannot be judged to have become an electoral democracy (Amnesty International 2012).

Furthermore, power consolidation by the CNDD-FDD has prevented the judicial and legal systems from becoming institutionalized. In fact, the government has resorted to judicial and legal repression. The National Liberal Forces (NLF), another Hutu faction, was blamed for the massacre that took place on September 18, 2011 and left 40 people dead. According to a report by Human Rights Watch, "Almost all political killings by individuals affiliated with the CNDD-FDD or the security forces were conducted with impunity. In some cases, the police or the prosecutor opened investigations, but these rarely led to arrests." However, the report adds, "When crimes were believed to have been perpetrated by opposition groups, the typical government response was to arbitrarily target FNL or ex-FNL members, even when there was no credible evidence that the individuals punished were responsible for these crimes" (Human Rights Watch 2012a). At present the judiciary can do little since it enjoys no real political independence, still proves unable to handle politically sensitive cases, and remains incompetent and resource-poor. According to the 2013 Index of Economic Freedom, "The constitution guarantees the independence of the judiciary, but judges are appointed by the executive branch and subject to political pressure. Transparency International calls Burundi the most corrupt country in the region. Corruption is pervasive; sales of government property frequently lead to allegations of bribery and cronyism" (Index of Economic Freedom 2013b).

\section{Sierra Leone}

Sierra Leone has proved to be a more successful case than Cambodia, TimorLeste, and definitely Burundi, when assessed in terms of the four areas discussed 
in this study. Sierra Leone gained independence from Britain in 1961 but then experienced political violence and civil war. Under his All People's Congress (APC) party, Prime Minister and later President Siaka Stevens turned his country into a one-party state until his retirement in 1985. In 1991 the country plunged into a civil war when the Revolutionary United Front (RUF) launched a guerilla insurgency from Liberia. The civil war did not end until the early 2000s, after a series of peace negotiations that led to the signing of the Lomé Peace Agreement and the subsequent deployment of UN peacekeepers.

The DDR process began in 1998 and went through various phases. It is generally regarded as a success story and has been a model for other countries, including Burundi. Some 31,000 small arms and light weapons were collected and destroyed. A total of 72,490 combatants were disarmed and 71,043 demobilized (although many of them were demobilized more than once because of the repeated resurgence in fighting). More than 63,000 former combatants, including 6,845 child soldiers, were also reintegrated into society (Solomon and Ginifer 2008; Miller, Ladouceur, and Dugal 2006).

Economic development has also become more evident in recent years. GDP expanded from 6\% in 2011 to $16.7 \%$ in 2012, was projected to stabilize at around $7.2 \%$ in 2013, and then expand again in 2014. The country has been able to attract foreign business. Foreign companies have expanded their business interests in the lucrative diamond mining industry. Investments in infrastructure have also increased.

There has also been clear progress on the democratic front. The presidential and parliamentary elections in 2002 resulted in the reelection of President Ahmad Tejan Kabbah of the Sierra Leone People's Party (SLPP), representing a defeat for the APC. However, the subsequent election in 2007 resulted in the APC's victory, as it won $55 \%$ of the vote and gained a slight majority in Parliament. Between 2009 and 2011, chieftaincy elections as well as parliamentary and local council by-elections were held, but they were marred by political violence committed by supporters of the two parties that also divided along regional lines. But political violence began to subside in 2012 after all parties signed an agreement in May committing to free, fair, and peaceful presidential and parliamentary elections scheduled for November. In both elections, the APC won, having gained 59\% of the presidential vote and increasing its parliamentary majority from 59 to 69 seats. Although the SLPP at first refused to accept the results, the leaders of the two parties issued a joint statement in December of that year recognizing the APC's victory. The 2012 elections were considered to be generally free, fair, and peaceful and were regarded as a milestone for the consolidation of peace and democracy.

The judicial and legal systems have also become better institutionalized than in the cases discussed above. The judiciary has enjoyed a higher degree of independence. In spite of continuing corruption, police unprofessionalism, low 
salaries, and a lack of resources, trials have been generally free and fair. A case can be made that the Special Court for Sierra Leone has had some positive impact on the judicial and legal systems. Since it began its operation in 2004, the Court has succeeded in convicting those responsible for large-scale human rights violations during the civil war. Former President Charles Taylor, accused of supporting the RUF insurgency, was arrested, tried, convicted of 11 counts of war crimes and crimes against humanity, and sentenced to 50 years in prison.

This does not mean that all is now well in Sierra Leone. Before the 2012 elections, provocative and extreme language was still evident at campaign rallies. Corruption remains endemic. Judicial institutions are still too weak to be independent and effective. Police brutality still takes place. Transnational crime continues to threaten the rule of law-although the Sierra Leone Transnational Organized Crime Unit, supported by the UN's West Africa Coast Initiative, has registered some successes in recent years. The economy remains largely dependent on agriculture and natural resource extraction. Poverty persists: according to the UNDP, "Poverty remains widespread with more than $60 \%$ of the population living on less than US\$1.25 a day and unemployment and illiteracy levels remain high" (UNDP 2013; Castañeda 2009).

In short, peacebuilding in Sierra Leone can be judged as a relative success story, followed by Timor-Leste, Cambodia, and Burundi. Once a country with one of the worst human rights abuse records in Africa, the country has now become more peaceful. Armed conflict ended, peace has been consolidated, and it has become more democratic than any of the other three countries. The question is: what explains this variation? Answers are bound to vary depending on the theoretical perspective one adopts. However, different perspectives help us explain why the promise of neo-liberal peacebuilding has its limits in practice and show how its potential for greater success can still be tapped.

\section{Explaining the Limits and Potential of Peacebuilding}

There is no question that liberal perspectives help explain some progress in all of these four cases. One thing they have in common is that the process of peacebuilding began after the end of periods of armed conflict. The process of disarmament, demobilization, and reintegration has proved to be more successful than critics claim. New democratic, judicial, and legal institutions have also been established with varying degrees of success. In particular, the cases of Cambodia and Burundi show that authoritarian peace has been maintained by political violence and intimidation. Democratic, judicial, and legal institutions have been established, but are still subject to political control. The cases of Timor-Leste and Sierra Leone, however, have proved to be relatively more successful.

This variation requires further explanation. Conflict termination, 
disarmament, and/or demining experiences have been more positive than negative in all cases, but this was not a result of retributive justice being successfully executed. Retributive justice in war-prone societies tends to undermine the perceived security of warring factions (especially those who have committed crimes), thus weakening the incentive for them to end war or disarm voluntarily (Peou 1997; Adekanye 1997; Pankhurst 1999; William and Scharf 2002; Zartman and Kremenyuk 2005). The post-1999 armed clashes in Timor-Leste and the subsequent return to peace and stability also had little to do with the success or failure of retributive justice. The armed clashes in 2006, for instance, resulted from the firing of 600 F-FDTL troops and their frustration over rampant corruption and high levels of unemployment, not from the actions of those who had committed crimes in the pre-1999 period. Other factors can better explain the causes of armed politics and instability. Socio-economic conditions remained poor. In 2002 , between $85 \%$ and $90 \%$ of urban adults were unemployed. In 2006 , about $40 \%$ of the population lived below the poverty line. Nearly half of East Timorese were illiterate. Even by the late 2000s, the unemployment rate remained around $50 \%$. The economy relied mainly on small-scale coffee production. Timor-Leste remains the poorest country in Southeast Asia (Smith 2003, 16; TLAVA 2009, 2). It was poor socio-economic conditions and weak institutional capacity (not the lack of retributive justice dealing with past abuses) that led to violent incidents. The fact that Timorese leaders have placed emphasis on development has little to do with Asian cultural values but more do with the country's desperate socio-economic needs. As noted, the government has since sought to address the socio-economic needs by spending more resources to stimulate the economy and keep it growing.

Cambodia and Timor-Leste further show that peace was the byproduct of political reconciliation and inclusive politics, not retributive justice (Newman and Richmond 2006; Peou 1997). In fact, the era of peace in Cambodia was ushered in after the Khmer Rouge movement had disintegrated and before the ECCC had begun its operation in 2007. The Khmer Rouge disintegration resulted from a series of formal and informal amnesties. Evidence further shows that peace in Timor-Leste had more to do with political reconciliation (Taylor 2002, 2; Budi 2008). The trials did not deter the armed violence that occurred in 2003, 2004, and 2006. A more rigorous pursuit of justice would have exacerbated the political tensions that existed. Tension resumed in October 2006 when the United Nations published the report of its Special Commission of Inquiry for East Timor, which blamed Prime Minister Alkatiri for the violent uprising and for his failure to prevent the transfer of weapons to civilians; it also implicated the former interior and defense ministers, and called for the prosecution of those responsible for activities leading to the 2006 uprising (United Nations 2006). Political tensions were reduced and peace returned after charges against Prime Minister Alkatiri were dropped. Peace between Timor-Leste and Indonesia also resulted from the 
fact that the governments of the two states chose not to pursue retributive justice but instead saw political reconciliation as a path forward. In August 2005, for instance, the two governments established the bilateral Commission on Truth and Friendship.

Democratization has met with greater success in Timor-Leste and Sierra Leone than in Cambodia and Burundi; however, neither case supports the argument that retributive justice effectively helps advance democracy. The threat of retributive justice made it difficult for the Cambodian factions-especially the Khmer Rouge, who knew that they would lose in the 1993 elections-to compete peacefully in the electoral process (Peou 1997). Nor did the recent Khmer Rouge trials help consolidate democratic politics. Although the pursuit of retributive justice failed in both Timor-Leste and Indonesia (Economist 2014), the two countries have become more democratic than Cambodia.

Retributive justice may have hindered the process of democratization in Burundi. President Pierre Nkurunziza has been critical of the International Criminal Court; in particular, he has criticized the arrest warrant against Sudanese President Omer Hassan Al-Bashir. Furthermore, according to one report, "Nkuranziza, himself a Hutu, has been implicated in complicity with mass killings, assassinations and torture at the hands of his security agents" (Graeber 2007). As the leader of the National Council for the Defense of Democracy (CNDD-FDD), whose members were former armed rebels who allegedly committed crimes but were granted provisional amnesties through a ceasefire agreement in 2003, the president has shown weak or no political will to pursue justice (Nshimirimana 2012). In July 2011, he promised to create a truth and reconciliation commission whose role would be to provide accountability for past abuses, but little progress has been made. Instead, more and more opposition members and journalists critical of government officials have been arrested; extrajudicial executions have continued.

Critical scholars and realists provide additional insights that help shed some light on the limits of neo-liberal peacebuilding through retributive justice. One of the consequences is that violent conflict and tension may arise from retributive justice. Judicial measures such as indictment may exacerbate tensions, increase atrocities, upset local amnesties, and undermine peace negotiations. Chandra Lekha Sriram, for instance, contends that retributive "justice processes and mechanisms may, like liberal peacebuilding, destabilize post-conflict countries" (Sriram 2009, 112, 119-120). According to some realist-inclined scholars, such as Jack Snyder and Leslie Vinjamuri, the prosecution of perpetrators of atrocities according to universal standards "risks causing more atrocities than it would prevent, because it pays insufficient attention to political realities" (Snyder and Vinjamuri 2003/04, 5). They reinforce this point: "When a country's political institutions are weak, when forces of reform there have not won a decisive victory, and when political spoilers are strong, attempts to put perpetrators of atrocities 
on trial are likely to increase the risk of violent conflict and further abuses, and therefore hinder the institutionalization of the rule of law" (Snyder and Vinjamuri $2003 / 04,15)$. If there is one thing that international liberal peacebuilders should learn from critical and realist scholars it is the need to let local and national actors pursue non-punitive policies. It should thus come as no surprise that new political regimes tend to opt for other forms of reconciliation instead of pursuing retributive justice (Kim and Ganesan 2013).

More attention should be focused on democratic state institution-building and economic development. Much emphasis has been placed on strengthening civil society, but civil society actors are unlikely to maintain peace if democratic state institutions remain fragile. Repressive regimes tend to be fragile and insecure but are generally capable of weakening or destroying civil society organizations. Attempts to first meet all local expectations and demands may hinder peacebuilding efforts because of "deep divisions at the grassroots" (Chigas and Woodrow 2009, 50). Deep divisions at the grassroots can deepen further if political elites are still at war with each other, and can politicize local communities. Calls for local empowerment should not override strengthening democratic state institutions. Any attempts to divide states along ethnic lines may have considerable political appeal, but this policy strategy may encourage ethnic intolerance and state disintegration. Instead, ethnic tolerance should be encouraged and institutionalized as part of inclusive democratic politics (Blagojevic 2007). Cambodia and Burundi, for instance, clearly show that communities or groups that share the same ethnic identity are still capable of waging war against each other for various other reasons, such as ideological struggles and fragile state structures. Without adequate state capacity, effective policy decision-making, and implementation it is difficult to sustain political and economic development. Without effective democratic state institutions, economic development is likely to mostly benefit the ruling elite. In short, only when democratic state institutions are first built and strengthened can civil society be strengthened to help raise the quality of democracy and economic justice.

If their neo-liberal agenda is going to be more successful, international peacebuilders must also learn to do more with less and do fewer things better and more effectively. This argument also means that peacebuilders must learn what works and what does not work, and devote more resources to doing what works. They should take some advice from realists who argue that states remain the dominant players in global politics and still care about themselves more than they care about other states. Expecting states to become more altruistic is unrealistic, unless states that need help also know how to help themselves.

The limits of peacebuilding can further be explained in terms of the persistent weak commitment of international donors to the developing world. The commitment to provide needy countries with more technical and financial assistance has been hampered by the overall decline in ODA in recent years. If 
ODA was increased in the early 2000s, it was also because of the threat of global terrorism. States still pursue their national security interests. According to the United Nations, "The world is over-armed and peace is under-funded." According to a UN report in 2012, the world spends more than \$1.6 trillion on defense, with the United States being the biggest spender (almost $\$ 700$ billion). In comparison, the annual expenditures on peace in the following areas are much smaller: $\$ 0.65$ billion on international disarmament and nonproliferation organizations, $\$ 2.7$ billion on the UN budget, and \$44 billion on international development assistance to the least or less developed countries (UNODA 2012).

\section{Conclusion}

If the process of peacebuilding is largely about preventing a relapse into armed conflict, then the four case studies presented here show that the neo-liberal agenda has proved to be more successful than critics think. Armed politics came to an end in Cambodia (1998), Timor-Leste (1999), Sierra Leone (2003), and Burundi (2006). This optimistic observation does not suggest that armed violence ends quickly when the process of peacebuilding begins. It is worth keeping in mind that peacebuilding is an ongoing but messy process (Fischer 2009, 91). Time may be an important variable explaining the trajectory of peacebuilding, but time alone does not determine whether peacebuilding succeeds or fails. Burundi, for instance, came into the game later than Sierra Leone, and this may help explain the latter's relative success. However, as the earliest of the four cases, Cambodia has proved to be less successful than Timor-Leste and Sierra Leone on the democratic front. Overall, there is room for cautious optimism about these cases and others. The question is not whether this global enterprise is a waste of time and should be abandoned but what else can be done to make it more effective, given the constraints identified earlier.

These case studies show that relatively successful peacebuilding efforts depend on how quickly warring factions can abandon the battlefield for the ballot box, and how economic development can help solidify democratic peace. At the early stages of peacebuilding, retributive justice does not have a significant positive impact on the process and may be counterproductive, especially when executed in countries where state institutions remain fragile and former warring factions find each other untrustworthy. Thus, more emphasis should be placed on democratic state institution building and economic development. Sierra Leone demonstrates that democratization need not impede economic development. Democracy, however, is not the only condition for economic development, just as economic development is not the condition for democratic transition (Crouch and Morley 1999, 328). Still, economic development helps provide political stability and consolidate democracy (Przeworski et al. 1996, 41) - just as it can 
help consolidate authoritarian rule (in Singapore, for instance). Democracies may come under threat when their economies fall into recession or collapse, as Greece shows, but democracy helps prevent economic crises from turning into armed conflict. Thus, sustainable peace must be based on both political democracy and economic development.

In short, disarmament, democracy, and development (DDD) as a joint project offers the best recipe for peacebuilding in post-war countries. Thus, first seek political and economic solutions that are beneficial to parties to conflict, and peace can then be consolidated by the institutionalization of retributive justice. Ask not, therefore, which perspective of peacebuilding is correct but what each perspective can teach us.

\section{Note}

I would like to thank the anonymous reviewers for their helpful comments on the manuscript.

\section{References}

Adekanye, J. Bayo. 1997. "Review Essay: Arms and Reconstruction in Post-Conflict Societies." Journal of Peace Research 34 (3): 359-366.

African Development Bank. 2011. Burundi Country Strategy Paper 2012-2016. TunisBelvedère, Tunis-Belvedere, Tunisia: Country Regional Department, East Africa.

Akhavan, Payam. 2001. "Beyond Impunity: Can International Criminal Justice Prevent Future Atrocities?” American Journal of International Law 95 (7): 7-31.

Akhavan, Payam. 2009. "Are International Criminal Tribunals a Disincentive to Peace? Reconciling Judicial Romanticism with Political Realism." Human Rights Quarterly 31 (3): 624-654.

Amnesty International. 2012. "Burundi.” In Annual Report 2012. https://www.amnesty.org/ en/region/burundi/report-2012 (accessed February 14, 2014).

Asian Development Bank. 2013. "Asian Development Outlook: Asia’s Energy Challenge." http://www.adb.org/publications/asian-development-outlook-2013-asias-energychallenge (accessed 20 July 2013).

Autesserre, Séverine. 2010. Peacetime Violence: Post-Conflict Violence and Peacebuilding Strategies. New York: City University of New York.

Avendano, Charlie, and Susan Brown. 2011. Taking Risks with Peace in Burundi: Ignoring Good Practice in Civilian Disarmament. Ottawa, Canada: Peacebuilding Centre Press.

Barnett, Michael, Hunjoon Kim, Madalene O'Donnell, and Laura Sitea. 2007. "Peacebuilding: What Is in a Name?" Global Governance 13 (1): 35-58.

Batchelor, Peter. 2002. "NGO Perspectives: NGOs and the Small Arms Issue." Disarmament Forum: 37-40.

Biersteker, Thomas J. 2007. "Prospects for the UN Peacebuilding Commission." 
Disarmament Forum 39: 37-44.

Blagojevic, Bojana. 2007. "Peacebuilding in Ethnically Divided Societies." Peace Review: A Journal of Social Justice 19 (4): 555-562.

Boutros, Boutros-Ghali. 1992. Agenda for Peace. New York: United Nations.

Brown, Anne, and Alex Freitas Gusmao. 2009. "Peacebuilding and Political Hybridity in East Timor." Peace Review: A Journal of Social Justice 22 (1): 61-69.

Budi, Setyo. 2008. "East Timor/Indonesia: Reconciliation at the Cost of Justice?" Inter Press Service News Agency (IPS), May 29.

Carothers, Thomas. 1999. Aiding Democracy Abroad: The Learning Curve. Washington, D.C.: Carnegie Endowment for International Peace.

Carothers, Thomas. 2000. "Taking Stock of US Democracy Assistance." In American Democracy Promotion: Impulses, Strategies, and Impacts, eds. Michael Cox, et al. Oxford and New York: Oxford University Press.

Castañeda, Carla. 2009. "How Liberal Peacebuilding May Be Failing Sierra Leone." Review of African Political Economy 120: 235-251.

Chigas, Diana, and Peter Woodrow. 2009. "Envisioning and Pursuing Peace Writ Large." In Peacebuilding at a Crossroads: Dilemmas and Paths for Another Generation, eds. Beatrix Schmelzle and Martina Fischer. Berghof Handbook for Conflict Transformation Dialogue Series No. 7. Berlin, Germany: Berghof Research Center for Constructive Conflict Management, 47-57.

Crouch, Harold, and James W. Morley. 1999. “The Dynamics of Political Change.” In Driven by Growth: Political Change in the Asia-Pacific Region, ed. James Morley. New York and London: M. E. Sharpe, 313-352.

Diamond, Larry. 1995. Promoting Democracy in the 1990s: Actors and Instruments, Issues and Imperatives. New York: Carnegie Commission on Preventing Deadly Conflict.

Economist. 2014. "Indonesia's Elections: Democracy's Big Bang." April 6. http://www. economist.com/news/asia/21600130-parliamentary-poll-next-week-has-muchbearing-presidential-one-july-democracys-big-bang (accessed April 10, 2014).

Evans, Gareth. 2008. The Responsibility to Protect: Ending Mass Atrocity Crimes Once and for All. The Brookings Institution, 154-156.

Feher, Michel. 2000. Powerless By Design: The Age of the International Community. Durham: Duke University Press.

Fischer, Martina. 2009. "Participatory Evaluation and Critical Peace Research: A Precondition for Peacebuilding." In Peacebuilding at a Crossroads: Dilemmas and Paths for Another Generation, eds. Beatrix Schmelzle and Martina Fischer. Berghof Handbook for Conflict Transformation Dialogue Series No. 7. Berlin, Germany: Berghof Research Center for Constructive Conflict Management, 87-97.

Fisher, Simon, and Lada Zimina. 2009. "Just Wasting our Time? Provocative Thoughts For Peacebuilders." In Peacebuilding at a Crossroads: Dilemmas and Paths for Another Generation, eds. Beatrix Schmelzle and Martina Fischer. Bergh of Handbook for Conflict Transformation Dialogue Series No. 7. Berlin, Germany: Berghof Research Center for Constructive Conflict Management, 11-35.

Freedom House. 2005. "Freedom in the World 2005: Burundi." http://www.freedomhouse. org/report/freedom-world/2005/burundi\#.U0gQOeZdWFc (accessed January 2, 2014).

Freedom House. 2012. "Freedom in the World 2012: Burundi." http://www.freedomhouse. 
org/report/freedom-world/2012/burundi\#.U0gRE-ZdWFc (accessed January 2, 2014).

Freeman, Mark. 2002. Truth Commissions and Procedural Fairness. Cambridge: Cambridge University Press.

Galtung, Johan. 1975. "Three Approaches to Peace: Peacekeeping, Peace-Making and Peace-Building." In Peace, War and Defence-Essays in Peace Research 2, eds. Christian Ejlers. Copenhagen, 282-304.

Gillespie, Richard, and Richard Youngs. 2002. The European Union and Democracy Promotion: The Case for North Africa. London: Frank Cass.

Goldstone, Richard. 1995. "Exposing Human Rights Abuses: A Help or Hindrance to Reconciliation." Hastings Constitutional Law Quarterly 22 (3): 607-621.

Graeber, Daniel. 2007. "The African Nation of Burundi Agrees to War Crimes Tribunals and Truth Commissions.” Foreign Policy Blog, May 24. http://foreignpolicyblogs. com/2007/05/24/the-african-nation-of-burundi-agrees-to-war-crimes-tribunals-andtruth-commissions/ (accessed August 6, 2013).

Hasegawa, Yuka. 2007. "Is a Human Security Approach Possible? Compatibility Between the Strategies of Protection and Empowerment." Journal of Refugee Studies 20 (1): $1-20$.

Heathershaw, John. 2008. "Unpacking the Liberal Peace: The Dividing and Merging of Peacebuilding Discourses." Millennium: Journal of International Studies 36 (3): 597621.

Heder, Steve. 2012. "Cambodia: Capitalist Transformation by Neither Liberal Democracy Nor Dictatorship." Southeast Asian Affairs 2012. Singapore: Institute of Southeast Asian Studies, 103-115.

Hughes, Caroline. 2009. “We Just Take What They Offer': Community Empowerment in Post-War Timor-Leste." In New Perspectives on Liberal Peacebuilding, eds. Edward Newman, Roland Paris and Oliver P. Richmond. Tokyo, New York, and Paris: United Nations University Press.

Human Rights Watch. 2011. "Burundi: Investigate Deadly Bar Shooting." September 20. http://www.hrw.org/news/2011/09/20/burundi-investigate-deadly-bar-shooting (accessed August 9, 2013).

Human Rights Watch. 2012a. "World Report 2012: Burundi." http://www.hrw.org/worldreport-2012/world-report-2012-burundi (accessed April 10, 2014).

Human Rights Watch. 2012b. "Burundi: Escalation of Political Violence in 2011." May 2. http://www.hrw.org/news/2012/05/02/burundi-escalation-political-violence-2011 (accessed August 9, 2013).

Huntington, Samuel. 1993. “The Clash of Civilizations?” Foreign Affairs 72 (3): 22-49.

Index of Economic Freedom. 2013a. “Timor-Leste.” http://www.heritage.org/index/ country/timorleste (accessed July 21, 2013).

Index of Economic Freedom. 2013b. "Burundi." http://www.heritage.org/index/country/ burundi (accessed July 21, 2013).

Jenkins, Rob. 2008. “The UN Peacebuilding Commission and the Dissemination of International Norms." Working Paper No. 38. London, UK: Crisis States Research Centre.

Joyner, Christopher. 1999. “The United Nations and Democracy." Global Governance 5 (3): 333-357. 
Katzenstein, Suzanne. 2003. Hybrid Tribunals: Searching for Justice in East Timor.” Harvard Human Rights Journal 16: 245-278.

Kim, Sung Chull, and N. Ganesan. 2013. "Introduction: Conceiving State Violence, Justice, and Transition in East Asia." In State Violence in East Asia, eds. Sung Chull Kim and N. Ganesan. Lexington, Kentucky: University of Kentucky.

Kumar, Krishna, and Jeroen de Zeeuw. 2006. "Democracy Assistance to Postconflict Societies." In Promoting Democracy in Postconflict Societies, eds. Krishna Kumar and Jeroen de Zeeuw. Boulder, CO: Lynne Rienner.

Mack, Andrew. 2008. "Global Political Violence: Explaining the Post-Cold War Decline." In Strategies for Peace: Contributions of International Organizations, States, and NonState Actors, eds. Volker Rittberger and Martina Fischer. Opladen and Farmington Hills: Barbara Budrich Verlag.

Miller, Derek, Daniel Ladouceur, and Zoe Dugal. 2006. From Research to Road Map: Learning from the Arms for Development in Sierra Leone. Geneva: UNDIR and UNDP.

Mitrany, David. 1966. A Working Peace System. Chicago: Quadrangle Books.

Muggah, H. C. R. 2001. "Globalization and Insecurity: The Direct and Indirect Effects of Small Arms Availability.” IDS Bulletin 32 (2): 70-78.

Muggah, Robert, and Martin Griffiths. 2002. Reconsidering the Tools of War: Small Arms and Humanitarian Action. London, UK: Humanitarian Practice Network.

Newman, Edward. 2009. “Liberal' Peacebuilding Debates.” In New Perspectives on Liberal Peacebuilding, eds. Edward Newman, Roland Paris, and Oliver P. Richmond. Tokyo, New York and Paris: United Nations University Press.

Newman, Edward, and Oliver Richmond, eds. 2006. Challenges to Peacebuilding: Managing Spoilers during Conflict Resolution. Tokyo, New York, and Paris: United Nations University Press.

Newman, Edward, Roland Paris, and Oliver P. Richmond, eds. 2009. New Perspectives on Liberal Peacebuilding. Tokyo, New York, and Paris: United Nations University Press.

Nindorera, Willy. 2012. The CNDD-FDD: The Path from Armed to Political Struggle. Berghof Transitions Series No. 10. Berlin, Germany: Berghof Research Center for Constructive Conflict Management.

Nshimirimana, Vital. 2012. "Transitional Justice in Burundi: Expectations and Concerns." Peace and Conflict Monitor, February 22. http://www.monitor.upeace.org/printer. cfm?id_article=874 (accessed August 6, 2013).

O’Dwyer, Diana. 2006. “First Landmines, now Small Arms? The International Campaign to Ban Landmines as a Model for Small-Arms Advocacy." Irish Studies in International Affairs 17 (1): 77-97.

Özerdem, Alpaslan, and Mark Knight. 2004. "Guns, Camps and Cash: Disarmament, Demobilization and Reinsertion of Former Combatant in Transitions from War to Peace." Journal of Peace Research 41 (4): 499-516.

Pankhurst, Donna. 1999. "Issues of Justice and Reconciliation in Complex Political Emergencies: Conceptualizing Reconciliation, Justice and Peace.” Third World Quarterly 20 (1): 239-255.

Paris, Roland. 1997. "Peacebuilding and the Limits of Liberal Internationalism." International Security 22 (2): 54-89.

Paris, Roland. 2006. "Bringing the Leviathan Back In: Classical Versus Contemporary Studies of the Liberal Peace." International Studies Review 8 (3): 425-440. 
Paris, Roland. 2009. “Does Liberal Peacebuilding Have a Future?” In New Perspectives on Liberal Peacebuilding, eds. Edward Newman, Roland Paris, and Oliver P. Richmond. Tokyo, New York, and Paris: United Nations University Press.

Penz, Peter. 2001. “The Ethics of Development Assistance and Human Security." In Ethics and Security in Canadian Foreign Policy, ed. R. Irwin. Vancouver, BC: University of British Columbia Press, 38-55.

Peou, Sorpong. 1997. Conflict Neutralization in the Cambodia War: From the Battlefield to Ballot-Box. Kuala Lumpur, New York, and Singapore: Oxford University Press.

Peou, Sorpong. 2007. International Democracy Assistance for Peacebuilding: Cambodia and Beyond. Basingstoke and New York: Palgrave Macmillan.

Peou, Sorpong. 2008. "Critical Challenges for Globalism in Human Security Studies." In Human Security in East Asia: Challenges for Collaborative Action, ed. Sorpong Peou. New York, NY and Oxon, UK: Routledge.

Peou, Sorpong. 2011. "Cambodia: A Hegemonic Party System in the Making." In Political Parties, Party Systems and Democratization in East Asia, eds. Liang Fook Lye and Wilhelm Hofmeister. Singapore and Hackensack, NJ: World Scientific.

Peou, Sorpong. 2013a. "Human Security in Post-Conflict Cambodia." In Development and Human Security in Asia, ed. Brenda Howe. Surrey, UK: Ashgate.

Peou, Sorpong. 2013b. "Mass Atrocities in Cambodia under the Khmer Rouge Reign of Terror." In State Violence in East Asia, eds. Sung Chull Kim and N. Ganesan. Lexington, KY: University of Kentucky.

Peou, Sorpong. 2014. "The Cambodian Challenge for Party and Party System Institutionalization." In Party and Party System Institutionalization in Asia. Cambridge: Cambridge University Press.

Przeworski, Adam, et al. 1996. "What Makes Democracies Endure?” Journal of Democracy 7 (1): 39-55.

Pugh, Michael. 2009. “Towards Life Welfare." In New Perspectives on Liberal Peacebuilding, eds. Edward Newman, Roland Paris, and Oliver P. Richmond. Tokyo, New York, and Paris: United Nations University Press.

Richmond, Oliver. 2003. "Introduction: NGOs, Peace and Human Security." In Mitigating Conflict: The Role of NGOs, eds. Henry F. Carey and O. P. Richmond. London, UK: Frank and Cass.

Rittberger, Volker, and Martina Fischer, eds. 2008. Strategies for Peace: Contributions of International Organizations, States, and Non-Non-State Actors. Opladen and Farmington Hills: Barbara Budrich Verlag.

Roht-Arriaza, Naomi. 1999. "Institutions of Justice." Journal of International Affairs 52 (2): 474-484.

Shoesmith, Denis. 2012. "Is Small Beautiful? Multiparty Politics and Democratic Consolidation in Timor-Leste." Asian Politics \& Policy 4 (1): 33-51.

Smith, Chris. 2000. "The 2001 Conference-Breaking Out of the Arms Control Framework." In Small Arms Control: The Need for Coordination, ed. Kerstin Hoffman. Geneva, Switzerland: United Nations Institute for Disarmament Research, 39-45.

Smith, Anthony L. 2003. "Constraints and Choices: East Timor as a Foreign Policy Actor." New Zealand Journal of Asian Studies 7 (1): 15-36.

Smith, Michael G. and Maureen Dee. 2003. Peacekeeping in East Timor: The Path to Independence. Boulder, CO: Lynne Reiner. 
Snyder, Jack, and Leslie Vinjamuri. 2003/04. "Trials and Errors: Principle and Pragmatism in Strategies of International Justice." International Security 28 (3): 5-44.

Solomon, Christina, and Jeremy Ginifer. 2008. Disarmament, Demobilization and Reintegration in Sierra Leone. Bradford, UK: Centre for International Cooperation and Security, University of Bradford.

Springer, Simon. 2010. Cambodia's Neo-Liberal Order: Violence, Authoritarianism and the Contestation of Public Space. London, UK: Routedge.

Sriram, Chandra Lekha. 2009. "Retributive Justice and the Liberal Peace." In New Perspectives on Liberal Peacebuilding, eds. Edward Newman, Roland Paris, and Oliver P. Richmond. Tokyo, New York and Paris: United Nations University Press.

Taylor, Rachel S. 2002. "Interview: East Timorese President Xanana Gusmao." Worldpress.org, October 1. http://www.worldpress.org/print_article.cfm?article_ $\mathrm{id}=851 \&$ dont $=$ yes $($ accessed April 20, 2011).

Thakur, Ramesh, and William Maley. 1999. "The Ottawa Convention on Landmines: A Landmark Humanitarian Treaty in Arms Control." Global Governance 5 (3): 273-302.

Timor-Leste Armed Violence Assessment (TLAVA). 2009. "Groups, Gangs, and Armed Violence in Timor-Leste." TLAVA Issue Brief, No.2, April. http://www.timor-lesteviolence.org/pdfs/Timor-Leste-Violence-IB2-ENGLISH.pdf (accessed January 12, 2014).

UNODA (United Nations Office for Disarmament Affairs). 2012. “The World Is OverArmed and Peace Is Underfunded.” August 30. http://www.un.org/disarmament/ update/20120830/http://www.un.org/disarmanent/over-armed (accessed April 10, 2014).

UNDP. 1994. Human Development Report 1994: New Dimensions of Human Security. New York: UNDP.

UNDP. 2013. "About Sierra Leone." http://www.undp.org/content/sierraleone/en/home/ countryinfo/ (accessed July 21, 2013).

United Nations. 2006. Report of the United Nations Independent Special Commission of Inquiry for Timor-Leste. October 2. Geneva, Switzerland: United Nations.

Weitsch, Martina. 2009. "Mobilizing Public Opinion for Peace: The Next Challenge for the Peacebuilding Communities." In Peacebuilding at a Crossroads: Dilemmas and Paths for Another Generation, eds. Beatrix Schmelzle and Martina Fisher. Berghof Handbook for Conflict Transformation Dialogue Series No. 7. Berlin, Germany: Berghof Research Center for Constructive Conflict Management, 59-68.

White, Nigel. 2002. The United Nations System: Toward International Justice. Boulder, CO and London, UK: Lynne Rienner Publishers.

William, Paul, and Michael P. Scharf. 2002. Peace with Justice? War Crimes and Accountability in the Former Yugoslavia. Lanham, MD: Rowman \& Littlefield.

Wilkinson, Adrian, and Anya Hart-Dyke. 2006. Evaluation of the EU SALW to the Kingdom of Cambodia, 2nd ed. Belgrade, Serbia: South Eastern and Eastern Europe Clearinghouse for the Control of Small Arms and Lights Weapons.

World Bank. 1998. Development and Human Rights: The Role of the World Bank. Washington, D.C.: World Bank.

World Food Program. 2013. "Fighting Worldwide Hunger: Timor-Leste." http://www.wfp. org/countries/timor-leste/overview (accessed July 20, 2013).

Zartman, William, and Viktor Alexsandrovich Kremenyuk. 2005. Peace Versus Justice: 
60 Sorpong Peou

Negotiating Forward- and Backward-Looking Outcomes. Lanham, MD: Rowman \& Littlefield.

Sorpong Peou is Professor and Chair of the Department of Politics and Public Administration, Ryerson University (Toronto). Prior to this appointment, he was Chair of the Department of Political Science at the University of Winnipeg, Professor of International Security at Sophia University (Tokyo), and Fellow and the Canada-ASEAN Fellow at the Institute of Southeast Asian Studies (Singapore). His major publications include Human Security Studies (World Scientific, 2014), Peace and Security in the Asia-Pacific (Praeger 2010), Human Security in East Asia, ed. (Routledge 2008), International Democracy Assistance for Peacebuilding: Cambodia and Beyond (Palgrave Macmillan 2007), Intervention and Change in Cambodia: Toward Democracy (St. Martin's Press, Institute of Southeast Asian Studies and Silkworms, 2001), and Conflict Neutralization in the Cambodia War: From Battlefield to Ballot-box (Oxford University Press, 1997). E-mail: speou@politics.ryerson.ca 